\title{
USING SOCIAL NETWORKS IN TEACHING ESP TO ENGINEERING STUDENTS
}

\author{
Nataliia Saienko \\ National Technical University of Ukraine "Igor Sikorsky Kyiv Polytechnic Institute”, Ukraine \\ saenko106@gmail.com \\ Oksana Semyda \\ National Technical University of Ukraine "Igor Sikorsky Kyiv Polytechnic Institute”, Ukraine \\ osemida@gmail.com \\ Inna Akhmad \\ National Technical University of Ukraine "Igor Sikorsky Kyiv Polytechnic Institute”, Ukraine \\ innakhmad737@gmail.com
}

\begin{abstract}
The present study examines students' and teachers' views on and attitudes to the use of different social networks in teaching English for specific purposes (ESP) to future engineers. It focuses on the types of work social networks can be used for, on language skills they help develop. The study was conducted with a survey method. The research was held at the National Technical University of Ukraine "Igor Sikorsky Kyiv Polytechnic Institute" and the sample was 170 full-time students of Energy Management and Energy Saving Institute and 60 lecturers of the Department of English for Engineering. It was conducted during December-February of 2019 - 2020 academic year. Within the context of the research, the students' and teachers' surveys were conducted. They were asked about their experience in using social networks and their application concerning university-related work and studies. The analysis of responses in the questionnaires showed that students and their teachers have a positive perception of using social media networks for English for specific purposes teaching in the classroom and outside. From the conducted research, we can conclude that using social networks is effective in ESP teaching and these advanced technologies can improve students' ESP proficiency, enhance their motivation for studying foreign languages, and can be used as corpora of authentic materials. The results of this research may be used for other studies concerning ESP teaching and technology application in this process.
\end{abstract}

Keywords: English for specific purposes; social networks; language teaching; language skills; ESP proficiency.

\section{Introduction}

The researchers' interest in social networks (SNs) is growing due to their popularity and scientists regard using social networks not only for social communication but also suggest a new educative approach in applying them.

Having analysed scientific works on using technological advances in language teaching, we can say there have been two waves of such advances. The first wave is marked by the appearance of computer technologies and the Internet use in the classroom for teaching and learning. It has marked the beginning of the era of computer-assisted language learning (CALL), that according to Garet (2009) should be based on pedagogy, theory, and technology. Further developments in technologies and language teaching brought about the concept of network-based language teaching (Arno-Macia, 2012) or the second wave in language teaching.

Many scientists became interested in researching SNs influence on the language learning process (Hadoussa \& Menif, 2019; Bernal \& Fondevila-Gascon, 2015). They consider that using SNs for language teaching can provide positive aspiration, promote the implementation of blended learning and help students develop their autonomy. Although, alongside with this research, we should mention the study of CarrióPastor (2015) on online activities for language learning. It showed that online collaborative activities did not improve learners' autonomy in the second language reading and writing skills. In this research, the author analysed the students' group chats and e-mails, where they were given different collaborative tasks, feedback and forum activities of the students. The results of the research led to the conclusion that online group work decreased students' autonomy, they are more dependent on 'stronger' students.

Modern educators face the necessity to pace with the modern educative trends and to satisfy students' needs in using digital smart technologies and modern online tools for teaching a foreign language. In this article, we are trying to explore how social networks and information available in these networks can be used for teaching English for specific purposes (ESP) to the engineering students. Our research is in line with the research of other scientists who studied the question of the network tools application for practising different language skills (Bozkurt \& Ataizi, 2015) and who investigated the issues of the SNs use (Espinosa, 2015;

Saienko, N., Semyda, O., \& Akhmad, I. (2020). Using social networks in teaching ESP to engineering students. Advanced Education, 14, 38-45. https://doi.org/10.20535/2410-8286.198083 
Majid \& Stapa, 2017; Hamat \& Abu Hassan, 2019). In their study, Akkoyunlua \& Erkanb (2013) survey on educators' and learners' attitudes to the use of technologies in the educational process. The significance of their study lies in the evaluation of the new technologies application, a positive result of which made possible future research in this sphere. It is an undeniable fact that modern technologies continue to be used for all sorts of specific language learning activities, such as speaking, reading and writing skills development. Previous research has shown that information and communication technologies seem to be particularly successful when integrated into project-based language learning, where English can be acquired naturally through themed activities and different subject disciplines (Pim, 2013). Thus, teachers should harness new technologies and create modern learning opportunities for their students. There exists a considerable body of literature on how ESP teachers use available modern tools to devise materials and create situations relevant to their students' needs (Arnó-Macià, 2012). These new technologies can be a real trigger for evolving new teaching approaches, and open new pathways of learning (Bozkurt \& Ataizi, 2015). Moreover, Kern (2013) analysing the use of modern technologies in educational settings, states that the ubiquity of technologies significantly affected their application for ESP learning. The new technologies are even more inevitable and of primary need in the context of ESP than for teaching general English. The scientist identifies the "hybrid" nature of ESP when an educator has to teach the language and the fieldspecific content. Therefore, the authors of the article support the opinion that ESP students strongly depend on the Internet and social networks where they can access appropriate material for studying English and the educators' mission is to help them with this aspect. Kavaliauskiene \& Ashkinazi (2014) included an investigation on the popular social networks among youngsters in Britain and the USA and this helped conclude what networks could be used for effective communication and learning. Acknowledging the popularity of certain social networks, scientists investigated the influence of different social networks such as Facebook, YouTube, Twitter (Hadoussa \& Menif, 2019, Lesiak-Bielawska, 2015, Almourashi, 2016) on different language skills of the ESP students. Allen \& Seaman (2010) conducted a lot of research within the context of on-line learning and showed that this kind of learning is inevitable today and our present research contributes to this field as well.

Based on results in the literature including the reports in review papers, investigations of the use of SNs for language learning have been insufficient. The literature review showed that conducted studies examined only a few SNs, they were limited by one language skill, or that researchers did not take into account students of tertiary institutions.

\section{Research aims}

This paper aims at evaluating the use of online SNs in ESP teaching as a way to engage and motivate students in language learning. To reach the aim, the following tasks were set:

1. to survey students' and teachers' views on the SNs use with the help of questionnaire and interview;

2. to examine the effectiveness of using social networks in ESP teaching to technical students and to find out their application in forming different language skills.

In the study, we hypothesise that using SNs in ESP benefits to the creation of interactive teaching / learning positive environment can motivate students and facilitate teaching, learning and interaction processes.

\section{Methods}

Research Design

The study presents mixed research. The quantitative research method relied on collecting and processing data through the use of the questionnaire and interviewing participants. The qualitative research method was focused on interpreting the information. In particular, we had to find out the benefits of the SNs use in the educational context and to interpret the opinion of the engineering students and their English language teachers about SNs application in the study process.

\section{Participants}

We surveyed 60 English language teachers and 170 engineering students of "Igor Sikorsky Kyiv Polytechnic Institute" during December, 2019 - February, 2020. The research participants were the students of different years of study of Energy Saving and Energy Management Institute taught the ESP course by different English language teachers. Concurrently, we surveyed the ESP teachers of the Department of English for Engineering (lecturers, senior lecturers and assistant professors) of faculty linguistics. This research complies with the ethics, all participants took part in this research on a voluntary basis and were not forced in any way. 


\section{Research Instruments and Procedures}

There were used four questionnaires with open-ended and closed-ended questions: two questionnaires were meant for students, and two - for teachers. The surveys of the teachers and students were conducted with the help of Google Forms service and the answers were automatically systematised, analysed and graphically presented.

The aim of the first questionnaire "Social Networks for Learning English" was to get information from the students about the type of work SNs were used for, and the type of content shared via such networks. The respondents had to choose from the suggested variants. The questions were the following:

1. Does your teacher use social media networks for teaching English?

a. Yes b. No

2. What social media networks listed below does your English teacher use for teaching English?

a. Facebook b. Instagram c. Twitter d. Youtube e. Viber f. Telegram g. other

3. Are these social networks used for

- groupwork in the class

- self-study work in the class

- self-study work at home

4. What content does your teacher send to you via social network?

a. Video content

b. Texts for reading

c. Grammar material and exercises

5. Do you enjoy using social networks for learning English?

a. Yes b. No

6. What devices do you usually use for learning via social networks?

The aim of the second questionnaire "Attitude to Using Social Networks for Studying English" was to find out the students' attitude to the SNs use in the study process. Students had to choose among given options presupposing answers "Agree" or "Disagree".

1. I enjoy studying English with social media networks.

2. I don't like using social media networks for learning English.

3. Using social media networks for studying English makes a lesson more interesting.

4. Using social media networks for studying English helps better understanding of technical language on my specialism.

5. Using social media networks for studying English facilitates learning new material.

6. Using social media networks for studying English facilitates communication between me and my group mates.

7. Using social media networks for studying English facilitates communication with my teacher.

8. Using social media networks for studying English makes me feel comfortable.

The aim of the third questionnaire "Social Networks for Teaching English" was to get teachers' views on the SNs use in ESP teaching. The teachers were asked about the way they used SNs, about types of work SNs applied for, and about the study content shared via them. The questions are given below:

- Do you use social media networks for teaching English?

- What social media networks listed below do you use for teaching English? a. Facebook b. Instagram c. Twitter d. Youtube e. Viber f. Telegram g. other

- Are these social networks used

- groupwork in the class

- self-study work in the class

- self-study work at home

- What content do you send via social network?
a. Video content
b. Texts for reading
c. Grammar material and exercises

- Do you enjoy using social networks for teaching English?

- How often do you use social media networks for teaching English?
a. Every lesson
b. Not often
c. Often 


\section{d. Sometimes}

The aim of the fourth questionnaire "Social Networks for Language Skills Development" was to investigate the appropriateness of the SNs for the language skills development. The teachers had to complete a Lykert-type questionnaire which was purposed to reveal their attitude to the SNs for language skills development choosing among the answers "Not helpful", "Slightly helpful", "Helpful", "Very helpful".

What is your attitude to:

1) using SNs for the development of reading skills?

2) using SNs for the development of speaking skills?

3) using SNs for the development of writing skills?

4) using SNs for the development of listening and comprehension skills?

5) using SNs for the development of grammar skills?

6) using SNs for the development of ESP vocabulary?

\section{Data analysis}

We sought to collect information about their views on SNs use for teaching ESP and how they estimate the efficiency of SNs for the studying process. The analysis of data contained two stages. First, the surveys of the teachers and students were conducted with the help of Google Forms service and the answers were automatically systematised, analysed and graphically presented. Secondly, the teachers analysed and compared the answers of the questionnaires.

\section{Results and discussion}

In recent years, social networks became a platform for learning activities and students are in the centre of such activities. The study of the social networks is gaining popularity and is in focus of scientific investigations. Following all the conducted research we could state that usually scientists pay attention to one social network (YouTube, Facebook, etc.) or one sample group (school students or students). In our research we are trying to make analysis within 2 sample groups simultaneously, i.e. students and their teachers and identify what SNs are used more often.

The conducted research included two blocks of questionnaires: one block was purposed for students and another block - for English language lecturers. Each block comprised of 2 surveys on revealing the views on the SNs use and what skills they help develop.

Let us consider and analyse the students' answers to the first questionnaire "Social Networks for Learning English". According to students' answers, their teachers mostly use Telegram (93\%) and YouTube (37\%) for giving tasks and providing study material for them. Communication via social media networks is used for the group work in the class as well as for the self-study work in the class or at home, and the teachers confirmed that they provide their students with different types of teaching content: video, text and grammar materials. And the results of our research are different from the research study on Social Media Sites conducted by Kavaliauskiene \& Ashkinazi (2014). Their research shows that most of online British and US users prefer Facebook to other social sites. Whereas, Twitter and Instagram are more popular among younger adults. Popularity of certain social networks might be explained by the preferences of some age group in a certain region at a certain period of time. As functions and features of these SNs are very similar so they cannot be a key reason for their choice.

The second questionnaire for students "Attitude to Using Social Networks for Studying English" is a two-grade Lykert-type questionnaire where students had to choose "Agree" or "Disagree" and the results can be clearly demonstrated by the chart given below (see Figure 1). This diagram demonstrates that in general, students are positive about SNs use for study and consider them as a facilitating tool in learning new material and as means that can facilitate communication.

Also, students were suggested to give their comments and expectations on social networks use. The respondent students proposed to post more interesting English language content in the chat. Among the obstacles, they mentioned the absence of a fast stable connection on-site.

Also,the students were asked about the devices they use for communication via social networks. The results showed that all the students (100\%) use their smartphones and sometimes, when being at home - their PCs. Scientists claim it makes sense as 'there is no need for the teacher to provide learners with the hardware to incorporate a mobile learning component into their teaching context' and smartphones are much cheaper than laptops and have all the necessary functions and possibilities as tools for learning (Etela, 2018; Pratibha, 2019). The online survey conducted in the USA in 2014 claims that users engage with major social networks predominantly via mobile and that desktop usage has largely lowered while mobile usage continues to increase. This fact can be regarded as a very new trend in social networking (Kavaliauskiene \& Ashkinazi, 
2014), newer social networks such as Instagram, Pinterest and Snapchat are almost exclusively for smartphones. Scientists consider learning through smartphones as a part of electronic learning that gives even more opportunities with smartphones because of their availability, price, and functionality. Students can easily collaborate on projects, work with images, edit videos, write blogs, and share bookmarks using networking tools. Their generation is called "digital natives", who grew up with digital technology, performing multiple activities simultaneously.

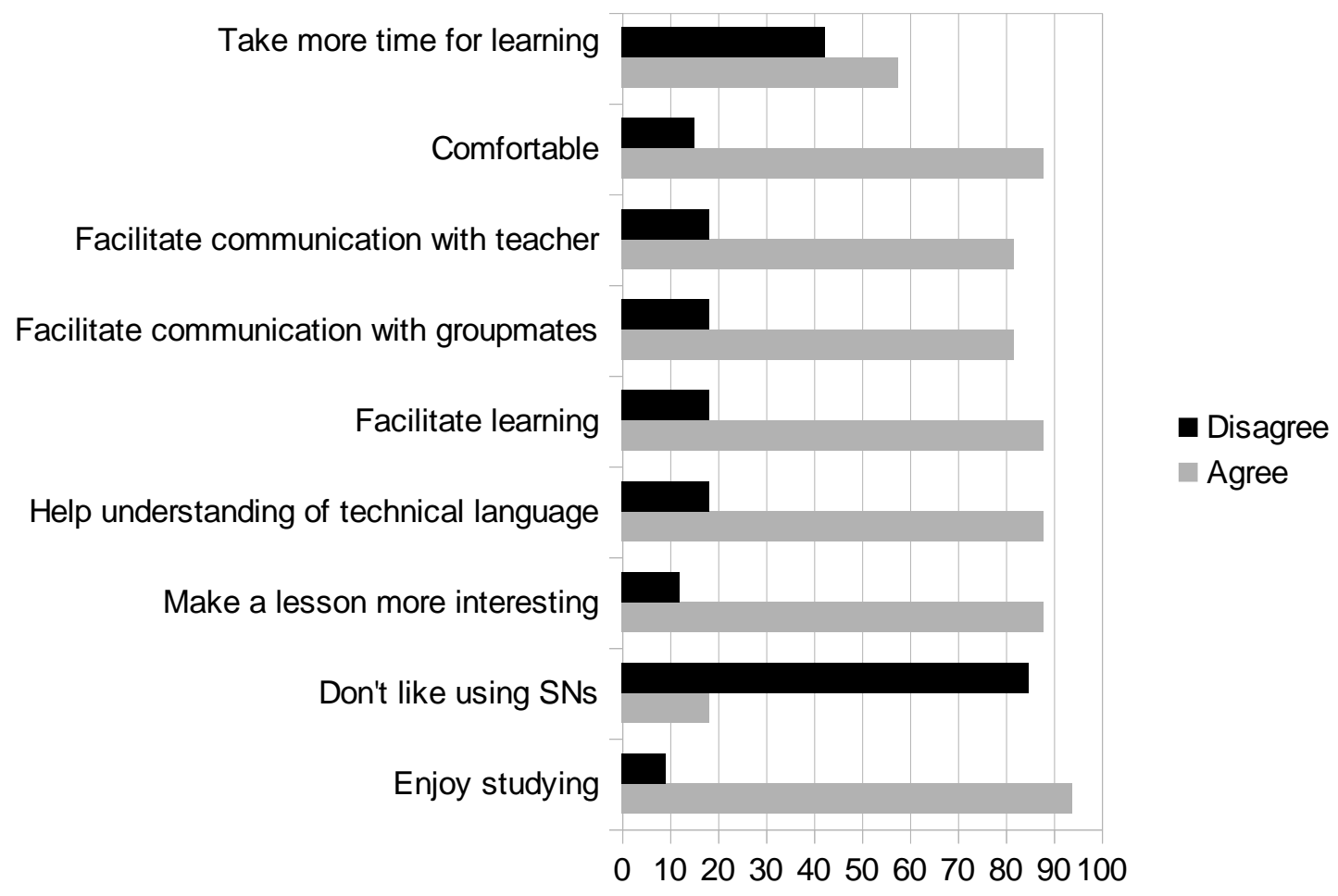

Figure 1. Attitude to Using Social Networks for Studying English

Let us consider the results of the teachers' questionnaire block. The results of the questionnaire "Social Networks for Teaching English" show that most teachers prefer using Telegram (68.4\%), YouTube (52.6\%) and Facebook (42.1\%) to other social networks like Viber (26\%) or Instagram (10\%). Sherman (2003), Almourashi (2016) having conducted research on YouTube video use for learning English got similar positive results. Researchers found that YouTube is an effective tool that can help improve the foreign language fluency, can help learners communicate and experience the events in the videos. Moreover, this kind of study material is authentic and it facilitates teachers to complete their tasks more effectively and efficiently (Almourashi, 2016). Interestingly, that neither teachers nor students use Twitter although it's a popular social network, it is gaining popularity. We see that teachers usually do not limit themselves to one network, they use different social networks depending on the material they want to share. Lecturers use social networks for different types of work but mostly for the group work $(79 \%)$ and for self-study work at home (79\%), and they tend to use less for self-study work in the class (31\%). Hammat \& Abu Hassan (2019) claim that the major attraction of academic use of SNs for educators is not only the number of students who are always logged in these sites. The SNs can facilitate and personalise communication process, collaboration and sharing teaching materials.

In the research Madge et al. (2009) and Dalsgaard (2006) came to the conclusion that students want social networks to be used by their professors to enhance their educational experience in terms of communicating assignments, providing details of the course, using it as a teaching tool and connecting with students using a technology which is already familiar to the students. Their research showed similar results to our research stating that students enjoy using social networks as a means of communication between them and their teachers, and between their group mates.

In the fourth questionnaire for the ESP teachers "Social Networks for Language Skills Development", the teachers were suggested to answer a four-grade Lykert-type questionnaire the results of which are demonstrated below (see Figure 2). 


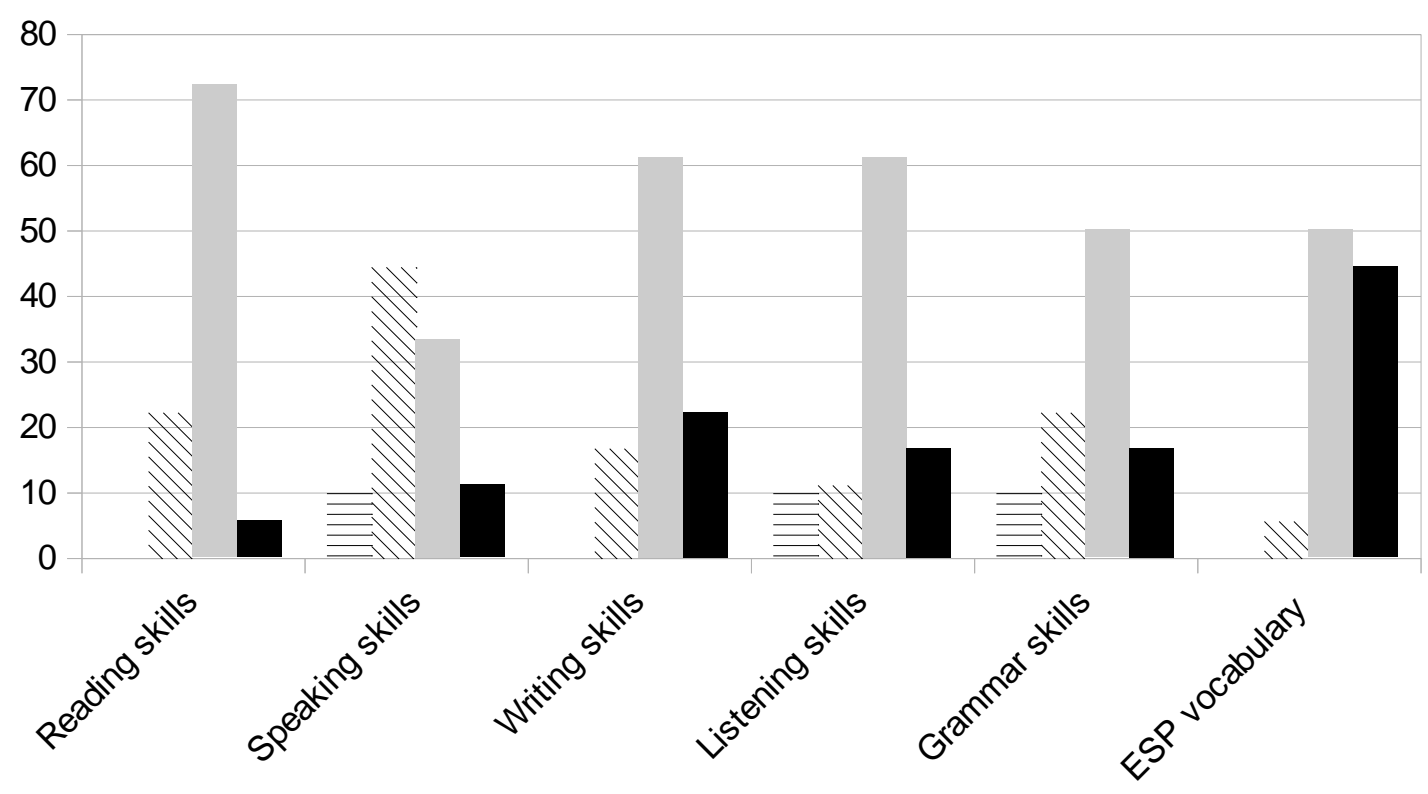

Figure 2. Social Networks for Language Skills Development

With reference to this survey results, we can state that teachers consider using social networks to be "very helpful" for learning ESP vocabulary. Also, the teachers regard SNs to be just "helpful" for the development of other language skills (reading, writing, listening and grammar). $44.4 \%$ of the respondent teachers consider SNs "slightly helpful" for the development of speaking skills as it is difficult to organise oral speaking with the help of SNs. This is in line with the research of other scientists who prove that social networks can be effectively used for the development of writing skills (Majid \& Stapa, 2017) and speaking skills (Omar et al, 2018). Scientists use the term "connectivism" to investigate how language skills can be acquired online via networks (Bozkurt \& Ataizi, 2015). It is a new way of knowledge acquisition, the next stage after behaviourism, cognitivism, and structuralism, that is in contrast to the conventional learning theories. We can employ the following social networks opportunities for developing language skills:

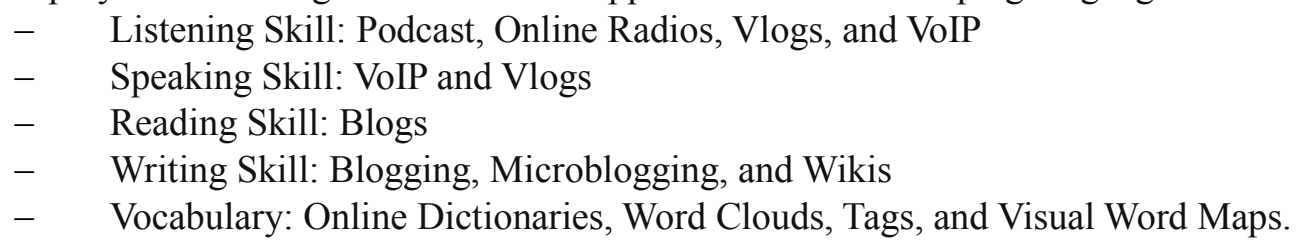

The rapid development of information technologies and the emergence of social networking have become a topic for many types of research in recent years. That is because nowadays the learning process is not limited by some educational institutions or in time. New opportunities are found with the development of information technologies. Modern social networks are a great contribution into the modern study process. Some scientists claim that in the nearest future an educational process will be stipulated by accessibility to online networks and online information where students can have access to the unique competencies and skills (Sokolyuk, 2016). In his research, the author studies the differences between social networks and Internet sites and services. We support the author's point of view that the main feature of such networks is the ability for online interaction and a combination of user's individuality with group work and thinking. The results of our second questionnaire "Attitude to Using Social Networks for Studying English" are also in line with stated above and show that respondent students $(81.8 \%)$ regard social networks as a communication facilitator between their group mates and teachers.

Scientists also focus their attention on studying the use of social networks for developing collaborative and cognitive and communicative skills (Hrynko, 2019). The research of Hrynko (2019) shows that students started to use social networks for studying more than several years ago. In 2017-2018, 90.3\% of respondents gave a positive answer about using social networks for study (Hrynko, 2019, p. 67). The same data is presented in our research on students' attitude to the SNs use (see Figure 1): $87.9 \%$ of students consider using social networks beneficial for learning the technical language on their specialism and the same part of the students consider that social networks can facilitate the learning process for them. They prefer to be involved in a shared activity. The results of our research are in line with the study of students engagement by Schindler et al. (2017) and YouTube use for classes by Almurashi (2016) who claim that engagement of the 
students in the joint learning activities increases due to the use of electronic social networking sites and that students feel happy and believe that modern technologies can improve studying process. Social media networks can provide behavioural, emotional, and cognitive students engagement. Our research (see Figure 1) proves the statement about all these types of engagement as $88 \%$ of students-respondents feel comfortable using social networks and $82 \%$ say that social networks facilitate communication between group mates. And $81 \%$ of students-respondents say that social networks can facilitate communication with their teacher. So, using these modern tools is envisaged to create a positive emotional atmosphere during the class which can be necessary and motivating for learning.

Concurrently, we surveyed their English teachers. The answers to the sixth question of the questionnaire "Social Networks for Teaching English" showed that 36.8\% respondent teachers use social networks for teaching activities "every lesson", $42 \%$ use "not very often", and $10.6 \%$ use SNs "sometimes". The teachersrespondents said that they also enjoy using social networks $(94.7 \%)$ but some of them $(5.3 \%)$ confess that they have doubts about how to use social networks. Lesiak-Bielawska (2015) also makes her notes on the psychological side of this. She presupposes that with the appearance of new technologies teachers may feel confused as to familiarising with the new ones and employing them.

In connection with this, we should mention the scientific investigation of Kern (2013, p.111) on integrating technologies in ESP where he points out the challenges of the technology integration in ESP. Teachers may face the issues of accessibility, availability, and reliability of the technology; the need for teacher and learner training; issues with time and resources needed for technology integration; new ways of managing classes; issues with changing roles of teachers and learners. Solving these problems could facilitate introduction of new technologies into the ESP course and make them a valuable addition to it.

Thus, the results of our research show that bringing together SNs and language learning process can motivate students, promote their engagement in communicative activities which could help enhance their language skills and competencies.

Also, here we should mention limitations of our research: it was limited by the number of respondents (lecturers of the Department of English for Engineering and students of Energy Saving and Energy Management Institute) but in any way, this research showed the tendencies in the ESP methodology and caused more interest to study this issue. Thus, in future, large-scale research might be conducted.

\section{Conclusions}

New information and communication technologies brought about changes in the teaching and learning process. These changes provoked the emergence of new teaching methods and new environments such as elearning, web-based learning, open and distance learning and blended learning. We think that an ESP teacher should accept such a challenge and be able to ensure up to date knowledge via technological advances and be ready to efficiently implement these advances into their teaching practice. Social networks provide unique opportunities for students' immersion into real situations, for creation of language speaking environment and supporting synchronous and asynchronous interaction. SNs are beneficial for a student studying autonomy as they can rely on themselves in finding interesting and appropriate information and it can be a good incentive for independent study, self-paced work, or special projects based on their interests. The research shows that teachers and students enjoy using SNs in ESP and consider it to be valuable, motivating and that can help introduce technological advances, thus making the study process interactive.

The findings of our research prove our hypothesis about the positive influence of SNs on the study process. Organising the study process in such a way could be motivating for the students, enhance their cognitive opportunities, promote their creative thinking, and develop new digital communicative skills, help them face the professional challenges.

Nevertheless, the research shows that despite technical issues and time needed to prepare materials, SNs are a viable educational solution to get students motivated and interested, to make studying more efficient, and to support teachers. Other studies are needed to make SNs more commonplace in the ESP teaching and reveal their advantages and benefits comprehensively.

As such, our visions for future research are: to examine and compare the effectiveness of the social networks use in ESP; to research the implementation of new technologies for teaching English; to research the long-term effects of the technological implementations.

\section{References:}

Akkoyunlua, B. \& Erkanb, S. (2013). A Study on student and teacher views on technology use. Social and Behavioral Sciences, 103, 68-76. https://doi: 10.1016/j.sbspro.2013.10.309

Allen, I.E., \& Seaman, J. (2010). Learning on demand: Online education in the United States, 2009. Babson Survey Research Group. 
Almurashi, W., A. (2016). The Effective use of YouTube videos for teaching English language in classroom as supplementary material at Taiban university in Alula. International Journal of English Language and Linguistics Research, 4 (3), 32-47. Retrieved 3 March 2020 from http://www.eajournals.org/

Arnó-Macía, E. (2012). The role of technology in teaching languages for specific purposes. The Modern Language Journal, 96, 89104. https://doi.org/10.1111/j.1540-4781.2012.01299.x

Bernal, M. P. \& Fondevila-Gascon, J.F. (2015). Facebook in the university environment: to what extent do students make use of social networking sites and instant messaging applications for university related work and studying? Proceedings of 9 th International Technology, Education and Development Conference, IATED (pp. 5663-5668). Retrieved 3 March 2020 from https://library.iated.org/

Bozkurt, A. \& Ataizi, M. (2015). English 2.0: Learning and Acquisition of English in the Networked Globe with the Connectivist Approach.Contemporary Educational Technology, 6 (2), 155-168. https://doi.org/10.30935/cedtech/6146

Carrió-Pastor, M.L. (2015). Do online collaborative activities foster autonomy on second language reading and writing? Language Teaching Tomorrow, 1, 1-6. Retrieved 3 March 2020 from http://urn.fi/urn:nbn:fi:jamk-issn-2343-0281-9

Dalsgaard, C. (2006). Social software: E-learning beyond learning management systems. European Journal of Open, Distance and ELearning, 2. Retrieved 3 March 2020 from http://www.eurodl.org/ma

Espinosa, L.F. (2015). The Use of Facebook for Educational Purposes in EFL Classrooms. Theory and Practice in Language Studies, 5(11), 2206-2211. http://dx.doi.org/10.17507/tpls.0511.03

Etela, P. (2018). The Effects of Using Mobile Phone SMS on Intentional and Incidental Vocabulary Learning by Iranian EFL Learners. Journal of Applied Linguistics and Language Research, 5(5), 35-46. Retrieved 3 March 2020 from http://www.jallr.com/index.php/JALLR/article/view/898

Garrett, N. (2009). Computer-assisted language learning trends and issues revisited: Integrating innovation. The Modern Language Journal, 93, 719-740. https://doi.org/10.1111/j.1540-4781.2009.00969.x

Hadoussa, S., Menif, H. (2019). Social media impact on language learning for specific purposes: A study in English for business administration. Teaching English with Technology, 19 (1), 56-71. Retrieved 3 March 2020 from $\mathrm{http} / / / c e j s h . i c m . e d u . p l / c e j s h / e l e m e n t / b w m e t a 1 . e l e m e n t . d e s k l i g h t-c 416 a 57 b-b 0 \mathrm{~d} 8-4068-9955-\mathrm{d} 5 \mathrm{f} 9172 \mathrm{f} 76 \mathrm{e} 6$

Hamat, A., \& Abu Hassan, H. (2019). Use of Social Media for Informal Language Learning by Malaysian University Students: The Southeast Asian Journal of English Language Studies, 25(4), 68 - 83. http://doi.org/10.17576/3L-2019-2504-05

Hrynko, V. (2019). Electronic social networking sites as a universal tool for developing future teacher's digital competence: Advanced Education, 6(12), 64-73. http://dx.doi.org/10.20535/2410-8286.168076

Kavaliauskienè, G. \& Ashkinazi, V. (2014). Social networking systems in teaching/learning English for specific purposes. English for Specific Purposes, 42 (15), 1682-3257. Retrieved from http://esp-world.info/Articles_42/Documents/Kavaliauskiene.pdf

Kern, N. (2013). Technology-integrated English for Specific Purposes lessons: real-life language, tasks, and tools for professionals. In G. Motteram (Ed.), Innovations in learning technologies for English language teaching (pp. 87 - 117). London: The British Council.

Lesiak-Bielawska, E.D. (2015). Technology in ESP Pedagogy. English for Specific Purposes World, 48 (16). Retrieved 3 March 2020 from http://esp-world.info/

Madge, C., Meek, J., Wellens, J. \& Hooley, T. (2009). Facebook, social integration and informal learning at university: It is more for socialising and talking to friends about work than for actually doing work. Learning, Media and Technology, 34(2), 141 155. https://doi.org/10.1080/17439880902923606

Majid, A. \& Stapa, S. (2017). The Use of Scaffolding Technique via Facebook in Improving Descriptive Writing Among ESL Learners. The Southeast Asian Journal of English Language Studies, 23(4), 77-88. http://doi.org/10.17576/3L-2017-2304-07

Omar A., Amir, Z., \& Mohamad, M. (2018). Facilitating Online Learning: Students' Online Discussion Strategies for a Project Work at a Technical University in Malaysia. The Southeast Asian Journal of English Language Studies, 24 (4), 102-114. http://doi.org/10.17576/3L-2018-2404-08

Pratibha, M. (2019). Language Learning and Teaching Using New Technologies. IRA International Journal of Education and Multidisciplinary Studies, 14(1), 14-20. http://dx.doi.org/10.21013/jems.v14.n1.p3

Pim, C. (2013). Emerging technologies, emerging minds: digital innovations within the primary sector. In G. Motteram (Ed.), Innovations in learning technologies for English language teaching (pp.15-42). London: The British Council. http://doi.org/10.13140/RG.2.1.4479.1129

Schindler, L. A., Burkholder, G. J., Morad, O. A., \& Marsh, C. (2017). Computer-based technology and student engagement: a critical review of the literature. International Journal of Educational Technology in Higher Education, 14(25). https://doi.org/10.1186/s41239-017-0063-0

Sherman, J. (2003). Using authentic video in the language classroom. Cambridge, U.K.: Cambridge University Press.

Sokolyuk, O. (2016). Vkliuchennia merezhnikh sotsialnykh servisiv u diiuchi modeli organizatsii navchannia uchniv [Inclusion of social networking services in the existing model of organisation of students' learning]. Information Technologies and Learning Tools, 5(55), 55-66. https://doi.org/10.33407/itlt.v55i5.1494 